\title{
PERBEDAAN EDUKASI KONSUMSI SAYUR DAN BUAH PADA ANAK SD MENGGUNAKAN METODE CERAMAH DENGAN ALAT PERAGA DAN MEDIA AUDIOVISUAL
}

\section{Differences in Vegetable and Fruit Consumption Education in Elementary School Children Using Lecture Methods with Props And Audiovisual}

\author{
Septian Emma Dwi Jatmika', Firnadea Ekarizky Safrilia ${ }^{2}$ \\ 1,2 Fakultas Kesehatan Masyarakat, Universitas Ahmad Dahlan \\ E-mail: septianemma@ikm.uad.ac.id
}

\begin{abstract}
The consumption of fruit and vegetables for children are quite less in Yogyakarta, it is around 93,6 percent Another effort to increase the consumption of vegetables and fruits are rising knowledge and attitude by health promotion with education methods used props and audiovisual media. This research was conducted to know the difference between lecture method with props and audiovisual media for children knowledge and attitude about the consumption of vegetables and fruits. This study was an experimental quasi study with a control group design of pretest and post test non-equivalent. The sampling research used purposive sampling with 55 students of 5 elementary grade. The test were use unpaired T tests. The result are shown that there was no different between lecturer methods with props and audiovisual media to children knowledge $(p=0,073)$ and attitude $(p=0,492)$ about consumed vegetable an fruits.
\end{abstract}

Keywords: consumption of vegetables and fruit, lecture methods, props, audiovisual

\section{ABSTRAK}

Di Yogyakarta anak yang kurang mengkonsumsi sayur dan buah masih sangat kurang yaitu 93,6 persen. Salah satu upaya meningkatkan konsumsi sayur dan buah tersebut adalah meningkatkan pengetahuan dan sikap dengan cara melakukan promosi kesehatan dengan metode penyuluhan ceramah menggunakan alat peraga dan menggunakan media audio visual. Penelitian ini dilakukan untuk mengetahui perbedaan metode ceramah dengan alat peraga dan media audiovisual terhadap pengetahuan dan sikap anak tentang konsumsi sayur dan buah. Penelitian ini merupakan penelitian quasi eksperimental dengan rancangan kelompok kontrol pretest dan posttest non ekuivalen. Pengambilan sampel penelitian menggunakan purposive sampling dengan 55 siswa kelas $5 \mathrm{SD}$. Pengukuran diuji menggunakan uji T tidak berpasangan. Hasil penelitian menunjukan bahwa Tidak ada perbedaan metode ceramah dengan alat peraga dan media audiovisual terhadap pengetahuan $(p=0,073)$ dan sikap $(p=0,492)$ anak tentang konsumsi sayur dan buah. Pihak sekolah dapat menambahkan program sekolah yang berhubungan dengan konsumsi sayur dan buah serta dapat mengembangkan metode penyuluhan maupun pembelajaran yang dibantu dengan media seperti metode ceramah dengan menggunakan media audiovisual dan alat peraga.

Kata kunci: konsumsi sayur dan buah, metode ceramah, alat peraga, audiovisual 


\section{PENDAHULUAN}

S ayur dan buah merupakan salah satu sumber makanan yang mengandung banyak zat gizi yang harus dikonsumsi manusia setiap kali makan. Tidak hanya bagi orang dewasa, mengonsumsi sayur dan buah sangat penting untuk dikonsumsi sejak usia anak-anak ${ }^{1}$. Konsumsi sayur dan buah pada anak saat ini masih sangat kurang, menurut Kemenkes tahun 2010-2013 menunjukkan bahwa secara nasional perilaku anak yang kurang mengonsumsi sayur dan buah masih diatas 90 persen dan ditahun 2014 97,7 persen untuk anak Indonesia kurang mengonsumsi sayur dan buah². Daerah Istimewa Yogyakarta yang makan sayur dan buah sampai tiga kali sehari hanya $15-16$ persen ${ }^{3}$.

Kurangnya pengetahuan dan sikap dapat mempengaruhi perilaku konsumsi sayur dan buah pada anak. Salah satu upaya meningkatkan pengetahuan dan sikap dalam perilaku konsumsi sayur dan buah adalah dengan cara melakukan promosi kesehatan dengan metode penyuluhan ceramah menggunakan alat peraga dan menggunakan media audio visual. Adanya pesan kesehatan kepada anak dapat merubah pengetahuan tentang kesehatan yang lebih baik, sehingga dapat berpengaruh terhadap perilaku 4 . Ceramah dapat dilakukan dengan kombinasi metode yang bervariasi. Salah satunya dengan menggunakan alat peraga. Alat peraga adalah alat bantu pendidikan yang digunakan dalam menyampaikan sesuatu atau bahan pengajaran, karena pengetahuan setiap manusia diterima atau ditangkap melalui panca indera sehingga pengetahuan yang diperoleh semakin jelas ${ }^{5}$. Media audiovisual adalah cara menyampaikan materi dengan menggunakan mesin-mesin elektronik untuk menyajikan pesan-pesan audiovisual. Penggunaan media audio visual sangat berperan penting untuk membantu masyarakat dalam memahami pesan dan informasi yang disampaikan. Penggunaan audiovisual sangat efektif untuk meningkatkan hasil belajar seseorang 4 .

Studi pendahulan yang telah dilakukan di SD Negeri Glagah Kota Yogyakarta didapatkan hasil wawancara dengan salah satu guru bahwa siswa memiliki kebiasaan makan yang bervariatif dan ada beberapa siswa yang tidak suka makan sayur, salah satu siswa mengatakan jika memakan sayur akan muntah. Hasil wawancara dengan siswa juga terdapat beberapa siswa yang tidak suka makan sayur dan buah dengan berbagai alasan seperti bosan, lebih suka makan cepat saji, ada buah yang berduri, kemudian beberapa siswa juga tidak mengetahui manfaat buah dan sayur karena saat ditanya beberapa pertayaan seputar buah dan sayur kemudian juga terlihat saat jam istirahat banyak siswa yang memilih jajan di luar sekolah. Kemudian kantin sekolah juga terlihat kecil di bawah tangga dan tidak menjual sayur dan buah. Sehingga dalam penelitian ini, peneliti ingin menilai pengetahuan dan sikap anak tentang konsumsi sayur dan buah dengan menggunakan metode ceramah dan alat peraga dengan ceramah dan media audiovisual.

\section{METODE PENELITIAN}

Metode penelitian yang digunakan adalah penelitian kuantitatif dengan desain penelitian quasi eksperimental. Penelitian ini subjek tidak dikelompokan secara acak, akan tetapi peneliti menerima keadaan subjek sesuai dengan rekomendasi guru. Rancangan penelitian yang digunakan adalah rancangan kelompok kontrol pretest dan posttest non ekuivalen. Lokasi penelitian dilakukan di SD Negeri Glagah kota Yogyakarta yang beralamat di Jalan Prof. Dr. Soepomo S.H., Janturan, Umbulharjo, Kota Yogyakarta, Daerah Istimewa Yogyakarta. Populasi pada penelitian ini adalah siswa kelas V tahun ajaran 2017/2018 dengan jumlah 2 kelas. Satu kelas berisi 28 siswa dan satu kelas lagi berisi 27 siswa. Teknik sampling yang digunakan adalah purposive sampling. Penggunaan purposive sampling ini untuk menunjukkan perlakuan yang berbeda sehingga sampel diambil sebanyak dua kelompok yaitu kelompok eksperimen yaitu kelas VB di SD Negeri Glagah Yogyakarta dan kelompok pembanding di kelas VC SD Negeri Glagah Yogyakarta. Instrumen pada penelitian ini adalah kuesioner dengan materi yang meliputi jenis sayur dan buah, anjuran konsumsi sayur dan buah, manfaat sayur dan buah, dan dampak tidak mengonsumsi sayur dan buah.

Penelitian ini menggunakan alat peraga berupa sayur dan buah asli serta audiovisual. Alat peraga yang berupa sayur dan buah asli 
sebagai alat bantu dalam menyampaikan intervensi mengenai konsumsi jenis dan macam sayur dan buah, kemudian alat peraga berupa foto atau gambar yang berisi gambar mengenai dampak dan manfaat mengkonsumsi sayur dan buah. Dan Audiovisual yang berupa video animasi mengenai konsumsi sayur dan buah. Dari 16 video peneliti menggunakan 7 video animasi yang bersumber dari youtube dengan keyword konsumsi sayur dan buah dan konsumsi sayur dan buah untuk anak. Total dari video-video tersebut yaitu 25: 00 menit. Video tersebut dipilih sesuai dengan ketentuan materi meliputi jenis sayur dan buah, manfaat sayur dan buah, dan dampak sayur dan buah.

Hipotesis dalam penelitian ini yaitu Ada perbedaan rerata antara pengetahuan dan sikap konsumsi sayur dan buah dengan menggunakan metode ceramah dengan alat peraga dan media audiovisual pada anak di SD Negeri Glagah Yogyakarta. Uji yang dilakukan adalah Uji Mann Whitney digunakan untuk mengetahui perbedaan pemberian intervensi dengan metode ceramah menggunakan alat peraga dan metode ceramah menggunakan media audiovisual, uji ini dilakukan karena sebaran data tidak berdistribusi normal.

\section{HASIL}

Penelitian ini dilakukan pada siswa kelas 5 SD dengan jumlah siswa sebanyak 55 anak yang terbagi menjadi 2 kelas. Kelas pertama adalah kelas 5C yang diberi intervensi menggunakan metode ceramah dengan alat peraga. Kelas kedua adalah kelas $5 \mathrm{~B}$ yang diberikan intervensi menggunakan metode ceramah dengan media audiovisual. Hasil pengetahuan dan sikap sesudah diberi intervensi dengan metode ceramah menggunakan alat peraga dan media audiovisual dapat dilihat pada Tabel 1 .

\section{Tabel 1}

Hasil Pengetahuan dan Sikap Sesudah Diberi Intervensi dengan Metode Ceramah Menggunakan Alat Peraga dan Media Audiovisual pada Siswa Kelas 5 SD Negeri Glagah Kota Yogyakarta

\begin{tabular}{llcccc}
\hline Variabel & Hasil & $\begin{array}{c}\text { Media } \\
\text { Audiovisual }\end{array}$ & $\begin{array}{c}\text { Persentase } \\
(\%)\end{array}$ & $\begin{array}{c}\text { Alat } \\
\text { Peraga }\end{array}$ & $\begin{array}{c}\text { Persentase } \\
(\%)\end{array}$ \\
\hline \multirow{3}{*}{ Pengetahuan } & Menurun & 3 & 10,72 & 3 & 11,11 \\
& Meningkat & 20 & 71,43 & 21 & 77,78 \\
& Sama & 5 & 17,85 & 3 & 11,11 \\
\cline { 2 - 5 } Sikap & Menurun & 1 & 3,57 & 6 & 22,23 \\
& Meningkat & 24 & 85,71 & 19 & 70,37 \\
& Sama & 3 & 10,72 & 2 & 7,40 \\
\hline \multicolumn{2}{c}{} & 28 & 100,00 & 27 & 100,00 \\
\hline
\end{tabular}

Tabel 2

Hasil Uji Mann-Whitney Test Pengetahuan dan Sikap Setelah Diberi Intervensi dengan Metode Ceramah Menggunakan Alat Peraga dan Media Audiovisual

\begin{tabular}{llllll}
\hline \multirow{2}{*}{ Variabel } & Variabel & Mean & Min & Max & $p$ \\
\hline \multirow{2}{*}{ Pengetahuan } & Media Audiovisual & 22,71 & 19 & 27 & \multirow{2}{*}{0,073} \\
& Alat peraga & 22,72 & 20 & 27 & \\
\multirow{2}{*}{ Sikap } & Media Audiovisual & 59,71 & 49 & 67 & \multirow{2}{*}{0,492} \\
& Alat peraga & 60,96 & 50 & 68 & \\
\hline
\end{tabular}


Berdasarkan Tabel 1, diketahui bahwa sebanyak 71,43 persen dari 28 siswa mengalami peningkatan pengetahuan sesudah diberikan intervensi dengan media audiovisual sebanyak 10,72 persen dari 28 siswa mengalami penurunan. Dan siswa yang tidak mengalami peningkatan sebanyak 17,85 persen dari 28 siswa dan diketahui bahwa sebanyak 77,78 persen dari 27 siswa mengalami peningkatan sesudah diberikan intervensi dengan metode ceramah menggunakan alat peraga, 11,11 persen dari 27 siswa mengalami penurunan. Dan siswa yang tidak mengalami peningkatan sebanyak 11,11 persen dari 27 siswa.

Pada variabel sikap diketahui bahwa sebanyak 85,71 persen dari 28 siswa mengalami peningkatan sikap sesudah diberikan intervensi media audiovisual, hanya 3,57 persen dari 28 siswa mengalami penurunan, siswa yang tidak mengalami peningkatan sebanyak 10,72 persen dan diketahui bahwa sebanyak 70,37 persen dari 27 siswa mengalami peningkatan sikap sesudah diberikan intervensi dengan metode ceramah menggunakan alat peraga, 22,23 persen dari 28 siswa mengalami penurunan. Dan siswa yang tidak mengalami peningkatan sebanyak 7,40 persen dari 27.

\section{BAHASAN}

Perbedaan pengetahuan antara kelompok metode ceramah dengan menggunakan alat peraga dan kelompok metode ceramah menggunakan media audiovisual menunjukkan bahwa tidak terdapat perbedaan rerata antara pengetahuan konsumsi sayur dan buah pada kedua kelompok tersebut karena hasil pada nilai sig (2-tailed) menunjukkan pada variabel pengetahuan dengan menggunakan alat peraga dan media audiovisual yaitu 0,073. Begitu juga pada hasil nilai rata-rata pengetahuan pada metode ceramah menggunakan media audiovisual dan alat peraga tidak jauh berbeda yaitu kelompok media audiovisual memiliki nilai 22,71 dan kelompok alat peraga memiliki nilai 22,72 .

Metode ceramah adalah salah satu cara menjelaskan suatu ide, pesan secara lisan kepada sekelompok pendengar. Penggunaan metode ceramah juga efektif untuk pendidikan kesehatan terhadap peningkatan pengetahuan ${ }^{6}$.
Sedangkan untuk melihat perbedaan metode ceramah dengan alat peraga dan media audiovisual terhadap pengetahuan dan sikap setelah diintervensi dapat dilihat pada Tabel 2.

Berdasarkan Tabel 2 bahwa nilai rata-rata pengetahuan pada metode ceramah menggunakan media audiovisual adalah 22,71 dan alat peraga adalah 22,72 sedangkan nilai rata-rata sikap pada metode ceramah menggunakan media audiovisual adalah 59,71 dan alat peraga 60,96 . artinya perbedaan nilai rata-rata pada media audivisual dan alat peraga sangat sedikit atau tidak jauh berbeda.

Perbedaan metode ceramah dengan menggunakan alat peraga dan media audiovisual dapat diliat dari nilai $p$ value atau nilai sig (2-tailed) pada Tabel 16. Hasil pada nilai sig (2-tailed) menunjukkan pada variabel pengetahuan dengan menggunakan alat peraga dan media audiovisual yaitu 0,073 dan varibel sikap dengan menggunakan alat peraga dan media audiovisual yaitu 0,492 yang berarti nilai sig (2-tailed) $>0,05$. Sehingga hasilnya adalah tidak ada perbedaan rerata antara pengetahuan dan sikap konsumsi sayur dan buah dengan menggunakan metode ceramah dengan alat peraga dan media audiovisual pada anak di SD Negeri Glagah Kota Yogyakarta

Ceramah dapat dilakukan dengan kombinasi metode yang bervariasi. Penggabungan metode dan media ditambah dengan memperhatikan karakteristik responden merupakan hal utama yang dijadikan pedoman bagi penelitian intervensi. Sehingga dalam hal ini penggabungan metode dan media seperti metode ceramah digabung dengan media audiovisual atau media alat peraga dapat mendukung meningkatnya pengetahuan siswa dengan baik .

Media audiovisual merupakan alat yang digunakan untuk meningkatkan kemampuan otak, khususnya ketajaman otak dan daya ingat, melalui media yang dapat didengar dan dilihat. Media audiovisual yaitu jenis media yang mengandung unsur suara dan gambar yang bisa dilihat. Salah satu tipe media audiovisual yaitu audiovisual gerak yang menampilkan suara dan gambar yang bergerak seperti film suara atau video. Pada penelitian ini media audiovisual yang digunakan adalah audiovisual gerak karena menggunakan film animasi 
bergerak yang memberikan informasi berupa pentingnya konsumsi sayur dan buah. Penggunaan media tersebut sangat efektif untuk meningkatkan hasil belajar seseorang karena melibatkan banyak panca indera sehingga informasi yang dilihat dan didengar mudah diterima ${ }^{8}$. Pemilihan audio visual sebagai media penyuluhan kesehatan dapat diterima dengan baik oleh responden. Karena media promosi kesehatan ini yang lebih menarik dan tidak monoton ${ }^{9}$ dan dapat meningkatkan pengetahuan $\operatorname{kesehatan}^{10}$. Video merupakan media yang dapat menggambarkan suatu objek yang bergerak bersama-sama dengan suara alamiah ataupun suara yang sesuai ${ }^{11}$.

Alat peraga dalam promosi kesehatan dapat diartikan sebagai alat bantu untuk promosi kesehatan yang dapat dilihat, didengar, diraba, dirasa atau dicium, untuk memperlancar komunikasi dan penyebarluasan informasi ${ }^{3}$. Biasanya alat peraga digunakan secara kombinasi, misalnya menggunakan papan tulis dengan photo bahkan benda atau alat aslinya. Keuntungan alat peraga yaitu dapat menghindari salah pengertian/pemahaman atau salah tafsir, dapat memperjelas apa yang diterangkan dan dapat lebih mudah ditangkap, menarik serta memusatkan perhatian dan memberi dorongan yang kuat untuk melakukan apa yang dianjurkan. Sesuai dengan teori diatas saat penelitian anak-anak dapat melihat dan memegang sayur dan buah asli selain itu juga dapat melihat dampak yang diakibatkan apabila tidak mengkonsumsi sayur dan buah melalui tambahan alat peraga yaitu foto yang ditampilkan di power point. Peningkatan pengetahuan pada post test terjadi karena pendidikan kesehatan disampaikan dengan metode ceramah interaktif dan demonstrasi yang menggunakan alat peraga ${ }^{12}$.

Berdasarkan keuntungan yang dimiliki dua kelompok tersebut, kelompok metode ceramah dengan menggunakan media audiovisual maupun kelompok metode ceramah menggunakan metode ceramah menggunakan alat peraga sama-sama memiliki kekuatan yang dapat meningkatkan pengetahuan. Penelitian ini menggunakan metode ceramah dengan alat peraga dan media audiovisual yang dapat mempengaruhi pengetahuan responden. Metode ceramah dengan alat peraga dapat dipengaruhi oleh indera pendengar, penglihat, peraba, pencium, perasa, sedangkan metode ceramah menggunakan media audiovisual dapat dipengaruhi oleh indera penglihat dan pendengar. Meskipun alat peraga lebih banyak melibatkan panca indera, namun pada penelitian ini alat peraga hanya melibatkan dua panca indera saja yaitu pendengar dan penglihat yang dapat mempengaruhi pengetahuan. Dari segi komunikasi kelas alat peraga dan kelas audiovisual sama-sama mendapatkan ceramah dengan materi yang sama dan untuk alat peraga yang digunakan menyesuaikan dengan materi yang ada di audiovisual. Sehingga hal ini menunjukkan bahwa tidak ada perbedaan antara metode ceramah dengan alat peraga dan media audiovisual terhadap pengetahuan anak sekolah.

Tingkat keberhasilan suatu informasi dapat dipengaruhi oleh metode yang tepat serta media pembelajaran seperti alat bantu pendidikan berupa alat peraga yang dikemas secara menarik ${ }^{12}$ dan penerimaan pesan melalui indera penglihatan adalah sebesar 90 persen sedangkan melalui indera pendengaran adalah sebesar 5 persen sedangkan 5 persen lainnya untuk pengcapan, penciuman dan perabaan ${ }^{13}$. Sehingga dapat disimpulakan kedua media tersebut dapat meningkatkan pengetahuan karena menggunakan banyak alat indera terutama indera penglihat.

Sedangkan Perbedaan sikap antara kelompok metode ceramah dengan menggunakan alat peraga dan kelompok metode ceramah menggunakan media audiovisual menunjukkan hasil bahwa tidak terdapat perbedaan rerata antara pengetahuan konsumsi sayur dan buah pada kedua kelompok tersebut karena hasil pada nilai sig (2-tailed) menunjukkan pada variabel sikap dengan menggunakan alat peraga dan media audiovisual yaitu 0,492 yang berarti nilai sig (2tailed) $>0,05$. Begitu juga pada hasil nilai ratarata pengetahuan pada metode ceramah menggunakan media audiovisual dan alat peraga tidak jauh berbeda yaitu kelompok media audiovisual memiliki nilai 59,71 dan kelompok alat peraga memiliki nilai 60,96.

Media Audiovisual merupakan salah satu media yang digunakan pada penelitian ini. Media ini merupakan media yang baik untuk digunakan saat promosi kesehatan karena media tersebut melibatkan banyak indra dalam proses pembelajaran. Media audiovisual 
mengandalkan pendengaran dan penglihatan dari sasaran, dimana penggunaan audiovisual melibatkan semua alat indera pembelajaran, sehingga semakin banyak indera yang terlibat untuk menerima informasi, semakin besar kemungkinan isi informasi tersebut dimengerti dan dipertahankan dalam ingatan. ${ }^{14}$ Proses pendengaran dan pandangan yang didapat dari media audiovisual ini dapat menumbuhkan minat peserta didik dan selain itu juga proses pembelajaran dapat berlangsung kapanpun dan dimana pun diperlukan sehingga mempercepat proses pemahaman dan memperkuat ingatan. Media audiovisual dapat mempengaruhi ketiga domain pembelajaran dengan meningkatkan pengembangan kognitif, mempengaruhi perubahan sikap dan ikut membangun keterampilan motorik. Media audiovisual memberikan stimulus pada pendengaran dan penglihatan, sehingga hasil yang diperolah lebih maksimal. ${ }^{15}$ Penggabungan pendengaran dan penglihatan mampun meningkatkan retensi motorik $^{16}$. Kognitif video dapat memperkuat pemahaman siswa dan secara afektif, video dapat memperkuat siswa dalam merasakan unsur emosi dan penyikapan dari pembelajaran yang efektif. ${ }^{17}$ Pada penelitian ini untuk lebih membangun sikap yang positif dalam konsumsi sayur dan buah selain menggunakan media audiovisual, penyampaian pesan dibantu juga dengan metode ceramah yang dapat menyampaikan materi secara lisan dan cocok untuk kalangan manapun.

Menurut Edgar Dale media audiovisual mempunyai banyak manfaat yaitu memberikan dasar-dasar konkrit untuk berfikir, membuat pembelajaran lebih menarik, memungkinkan hasil pembelajaran lebih tahan lama, memberikan pengalaman-pengalaman yang nyata, mengembangkan keteraturan dan kontinuitas berpikir, dapat memberikan pengalaman yang tidak diperoleh dengan cara lain membuat kegiatan belajar lebih mendalam efisien dan beranekaragam, dan dapat digunakan berulang-ulang. Selain itu Audiovisual memberikan kontribusi yang sangat besar dalam perubahan perilaku masyarakat, terutama dalam aspek informasi dan persuasi. ${ }^{18}$

Selain media audiovisual, alat peraga berupa buah asli dan foto juga merupakan media yang digunakan untuk memberikan intervensi mengenai sayur dan buah. seperti yang telah dijelaskan pada variabel pengetahuan alat peraga memiliki keuntungan yaitu dapat menghindari salah pengertian/pemahaman atau salah tafsir, dapat memperjelas apa yang diterangkan dan dapat lebih mudah ditangkap, menarik serta memusatkan perhatian dan memberi dorongan yang kuat untuk melakukan apa yang dianjurkan. Benda asli (objek) mempunyai intensitas yang paling tinggi untuk mempersepsikan bahan pendidikan ${ }^{19}$. Sikap responden yang diberikan penyuluhan menggunakan alat peraga berupa slide foto yang ditampilkan pada powerpoint sebagian besar dikategorikan sikap sangat baik yaitu 88,4 persen dan katagori baik sebesar 11,6 persen. ${ }^{6}$ Hal ini terbukti saat dilakukan post test setelah intervensi menggunakan alat peraga hasil sikap meningkat lebih baik dan pada saat intervensi melalui alat peraga foto, siswa dapat melihat akibat apabila tidak mengkonsumsi sayur dan buah secara rutin sehingga dapat menimbulkan rasa khawatir apabila tidak melakukan hal yang positif.

Kerucut pengalaman Edgar Dale menunjukkan bahwa media audiovisual melibatkan 30 persen memori yang bisa diingat oleh manusia karena sasaran dapat melihat dan mendengar. Posisi alat peraga berada pada tingkatan melihat demontrasi melibatkan 50 persen memori yang bisa diingat karena sasaran dapat melihat benda asli dan dapat memegang buah asli19. Posisi alat peraga memang lebih tinggi dibandingkan dengan media audiovisual namun dengan berbagai keuntungan media audiovisual yang disajikan dengan menarik dapat menyamai kedudukan alat peraga dan berdasarkan hasil post test pada kelas yang diberi intervensi menggunakan media audiovisual sikapnya meningkat sebanyak 85,71 persen dan hasil yang didapatkan pada kelas alat peraga yaitu 70,37 persen. Secara statistik hasil rata-rata post test tidak bermakna atau berbeda jauh, namun dapat dilihat bahwa dengan audiovisual lebih dapat meningkatkan sikap.

Pada penelitian ini keduanya juga diberikan metode ceramah yang melibatkan 20 persen memori yang dapat diingat oleh manusia sehingga keduanya sama-sama memiliki keuntungan yang dapat meningkatkan sikap. Edgar Dale juga menjelaskan bahwa pemberian pendidikan kesehatan pun akan lebih efektif dan optimal ketika menggunakan metode dan media 
pendidikan kesehatan yang melibatkan banyak indera. Penggunaan alat peraga atau media merupakan pengalaman salah satu prinsip proses pendidikan. Media sangat membantu di dalam melakukan penyuluhan agar pesanpesan kesehatan dapat disampaikan lebih jelas dan sasaran dapat menerima pesan tersebut dengan jelas dan tepat pula. Sesuai dengan penelitian yang telah dilakukan yaitu pemeberian edukasi tentang konsumsi sayur dan buah menggunakan metode ceramah dengan media audiovisual dan alat peraga.

Menurut para ahli indera, yang paling banyak menyalurkan pengetahuan ke dalam otak adalah mata yaitu $75-87$ persen. Sedangkan lainnya tersalur melalui indera yang lain. Dari pengetahuan tersebut akan tersalurkan kedalam sikap, jika pengetahuan baik maka akan mempengaruhi sikap yang baik juga ${ }^{4}$. Intervensi mengenai konsumsi sayur dan buah disekolah bertujuan untuk meningkatkan pengetahuan dan kesadaran sikap tentang pentingnya mengkonsumsi sayur dan buah untuk menurunkan angka penyakit seperti obesitas, penyakit mata, pencernaan, dan lainlain. Responden dalam penelitian ini adalah anak-anak sehingga peningkatan pengetahuan anak SD nantinya diharapkan dapat meningkatkan kesadaran sikap bahkan perilaku anak untuk mengkonsumsi sayur dan buah secara rutin. Keterbatasan penelitian pada penelitian ini adalah intervensi dilakukan hanya satu kali saja berdasarkan izin yang diberikan oleh pihak sekolah tempat penelitian dan waktu atau jam yang diberikan untuk intervensi ditentukan oleh pihak sekolah.

\section{SIMPULAN DAN SARAN}

\section{Simpulan}

Berdasarkan hasil penelitian yang telah dilakukan tentang perbedaan metode ceramah dengan alat peraga dan media audiovisual terhadap pengetahuan dan sikap anak tentang konsumsi sayur dan buah di SD Negeri Glagah Kota Yogyakarta dapat disimpulkan bahwa tidak ada perbedaan rerata antara pengetahuan dan sikap konsumsi sayur dan buah dengan menggunakan metode ceramah dengan alat peraga dan media audiovisual pada anak di SD Negeri Glagah Yogyakarta.

\section{Saran}

Kepada siswa siswi SD Negeri Glagah untuk lebih meningkatkan konsumsi sayur dan buah, seperti memakan sayur dan buah secara rutin. Pihak sekolah dapat membantu siswa sisiwi dalam mengkonsumsi sayur dan buah seperti menyediakan sayur dan buah di kantin dengan tampilan yang lebih menarik dan dapat memberikan peraturan atau jadwal siswa sisiwi untuk membawa bekal sayur dan buah. Selain itu dapat menambahkan program sekolah yang berhubungan dengan konsumsi sayur dan buah serta dapat mengembangkan metode penyuluhan maupun pembelajaran yang dibantu dengan media seperti metode ceramah dengan menggunakan media audiovisual dan alat peraga

\section{UCAPAN TERIMA KASIH}

Ucapan terima kasih kami sampaikan kepada Kepala Sekolah SD N Glagah Kota Yogyakarta yang telah memberikan izin penelitian.

\section{RUJUKAN}

1. Candrawati E, Wiarsih W, Sukihananto. Ketersediaan Buah Dan Sayur Dalam Keluarga Sebagai Strategi Intervensi Peningkatan Konsumsi Buah Dan Sayur Anak Usia Prasekolah. Journal Care. 2014; Vol. 2(3):31-40.

2. Delacosta, K., Kamariotaki, M.P., Pavlatou E. Can we asses pupil's science knowledge with animated cartoons? Procedia Social Behavioral Science. $\quad$ 2011;15 3272-3276. www.sciencedirect.com.

3. Departemen Kesehatan RI. Pedoman Pengelolaan Promosi Kesehatan Dalam Pencapaian PHBS. Jakarta; 2008.

4. Fitriani. Promosi Kesehatan. Yogyakarta: Graha IImu; 2011.

5. Sigit Hariyadi. Modul Vidio Sebagai Media Layanan Bimbingan Dan Konseling. Semarang: Sigit Hariyadi Press; 2012.

6. Nur Dani Sulistyawati. Efektifitas Alat Bantu Penyuluhan Slide Power Point Dengan Leaflet Tentang Kanker Servik Terhadap Sikap WUS Dalam Pemeriksaan IVA Di Desa Jatimulyo 
Dlingo Bantul Tahun 2014. Skripsi STIKES Yogyakarta. 2014.

7. Arlina Dhian. Pengaruh Pendidikan Kesehatan Melalui Metode Ceramah dengan Audiovisual terhadap Pengetahuan Ibu Tentang Menopouse di Dukuh Girimulyo, Kelurahan Gergunung, Kecamatan Klaten Utara. Skripsi Universitas Gadjah Mada, Yogyakarta. 2011.

8. Anggi Marsella. Efektivitas Alat Peraga dengan Media Audio Visual dan Alat Peraga Riil terhadap Peningkatan Minat dan Hasil Belajar Peserta Didik SMA N 3 Klaten Materi Fluida Dinamis. Skripsi Universitas Negeri Yogyakarta, Yogyakarta. 2017

9. Herlina. Perbandingan Metode Ceramah Dan Media Audio Visual Terhadap Pengetahuan Dan Sikap Remaja Putri Tentang Pemeriksaan Payudara Sendiri (SADARI) Di SMA Negeri 11 Kota Jambi Tahun 2015. Scientic Journal. 2015;4(1):112-116.

10. Kantohe ZR, Wowor VNS, Gunawan PN. Perbandingan Efektivitas Pendidikan Kesehatan Gigi Menggunakan Media Video dan Flip Chart terhadap Peningkatan Pengetahuan Kesehatan Gigi dan Mulut Anak. Journal e-Gigi. 2016;4(2):96-101.

11. Azhar Arsyad. Media Pembelajaran. Jakarta: Rajawali Press; 2011.

12. Astuti NR. Promosi kesehatan gigi dan mulut dengan metode ceramah interaktif dan demonstrasi disertai alat peraga pada Guru Sekolah Dasar sebagai fasilitator. Information Design Journal. 2013;2(2):16-25.

13. Azhar Arsyad. Media Pembelajaran. Jakarta: PT Raja Grafindo Persada; 2010.

14. Soekidjo Notoatmodjo. Promosi Kesehatan Dan IImu Perilaku. Jakarta: Rineka Cipta; 2007.

15. Sadiman. Media Pendidikan. Jakarta: PT Raja Grafindo Persada; 2010.

16. Maulana. Promosi Kesehatan. Jakarta: EGC; 2009.

17. Nurhidayat $O$, Tunggul $E$, Wahyno $B$. Perbandingan Media Power Point Dengan Flip Chart Dalam Meningkatkan Pengetahuankesehatan Gigi Dan Mulut.
Jounal of Public Health. 2012;1(1):3135. doi:10.1177/1403494814549494

18. Soekidjo Notoatmodjo. Promosi Kesehatan Teori Dan Aplikasinya. Jakarta: Rineka Cipta; 2010.

19. Edgar Dale. Audiovisual Methods In Teaching / Edgar Dale. New York: Rinehart And Winston; 1963.

20. Rosyidah dan Winarni. Efektifitas Ceramah dan Audio Visual dalam Peingkatan Pengetahuan dismenorea Pada Siswi SMA. Journal Gaster. 2016;14(2):90-99 